Original Research Paper

\title{
Do Firm Size and Financial Performance Affect Corporate Social Responsibility Disclosure: Employees' and Environmental Dimensions?
}

\author{
Mohammad Ebrahim Nawaiseh \\ Department of Accounting, Al-Zaytoonah University of Jordan, Jordan
}

Article history

Received: 20-01-2015

Revised: $19-11-2015$

Accepted: 26-11-2015

Email: Nawaisehmohd@yahoo.com m.nawaiseh@zuj.edu.Jo

\begin{abstract}
The paper empirically tests the impact of company size and financial performance on Corporate Social Responsibility Disclosure (CSRD), from the Employees' and Environmental Dimensions perspective with reference to the disclosure frequency and quality of these dimensions among Jordanian industrial public share holding companies; whether there is an impact of firm size measured by total assets, ROA, ROE and Leverage on Corporate Social Responsibility Disclosures levels toward employees' dimension (CSRD1) and the environmental activities Dimension (CSRD2) in the Jordanian public industrial firms. The paper analysis is based on contents disclosed in their annual reports for 2013. The study applies suggested CSRD checklist for measuring the extent of CSRD in annual reports of these companies. Regression analysis is used to examine this issue. This study describes from theoretical point-of-view, social responsibility activities, as well as some financial performance, and firm size. Then, an empirical review is gained of reports published by a representative sample from the industrial sector. An attempt has been made to verify if there is a correlation between CSRD1, CSRD2 contents disclosed, financial performance; profitability, Leverage and size. The paper found solid evidence to accept positive significant influence of company size on both types of CSRD dimensions; employees and the environment. It found a negative significant impact of leverage on CSRD both employees and environment- dimensions. However, the study showed a positive significant impact of operating performance measured by Return on Assets (ROA) for the sample on CSRD towards employees dimension only, the impact of ROA on CSRD towards the environmental dimension is positive and insignificant. The impact of ROE has negative insignificant on CSRD towards employees. Consequently, it showed Positive insignificant impact of ROE on CSRD towards environmental dimension. This paper opens a new research path in CSRD, financial performance and size, for a possible link between both variables; a matter that has not been previously explored in Jordanian Industrial Public Shareholding Companies.
\end{abstract}

Keywords: Corporate Social Responsibility Disclosure (CSRD), Financial Performance, Environment, Jordan

\section{Introduction}

There are 73 Jordanian industrial public shareholding companies listed in Amman Stock Exchange (ASE) in 2013. Literally, companies in Jordan prepares their annual reports at the end of each fiscal year, these reports contain more activities that are related to environmental affairs, employees and others. These activities may have effect on the company's financial performance or not. Stakeholders also claim that public shareholding companies should provide them with adequate information to judge the companies' performance and to assure that their investments or debts are in a rational way. Consequently, Stockholders think information disclosed by companies' annual reports about CSRD activities has the pivot role in boosting the financial 
performance of their companies. Moreover, Jordanian public companies believe that CSRD have a positive impact on the company's performance. On other words; disclosing of CSR activities through annual reports, can be considered as a good impression about companies' financial performance, if these companies not doing so, this leads to neglected indicators. Recently, many Jordanian companies have begun to give their priority to disclose some activities toward community and environmental activities due to stakeholders' pressure that might face. However, Jordan government has issued regulations to identify the role of organizations; like the current environment law in minimizing social and environmental hazards, such organizations have not given much attention to reducing their abnormal impacts on community and the environmental side. Moreover, the pressure for eliminating the negative social and environmental effects driven by Jordan companies' practices is minimal. However, there is no obligation to report CSRD activities, thus CSRD reporting is companies Voluntary disclosure and the majority of companies in Jordan didn't give any noticeable attention of Corporate Social Responsibility Disclosure (CSRD) in their annual reports; these companies have no any vision of the effect of CSRD on their performance. The reason for the lack of knowledge is correlated by the fact that there is no substantial supporting to disclose CSR activities in the annual reports, because this type of disclosure is freely chosen. This concern related to the relationship between CSR with Financial Performance (FP). The current paper participates to the literature regarding of industrial companies as well as the relationship between CSRD and Financial Performance (FP) in the developing country like Jordan which has received little importance. The literature for the relationship between Corporate Social Responsibility and financial performance studies is so scanty regarding the Arab region (Rettab et al., 2009). Other studies have indicated a positive relationship between Corporate Social Responsibility and financial performance as argued by Aras et al. (2008), whereas others have not. Orlitzky et al. (2003) investigate the causality relationship between corporate financial performance and social responsibility activities. Others were not able to find any significant relationship between corporate profitability and CSR activities on Australia's firms according to Brine et al. (2006), while other studies show insignificant relationship between CSR and corporate performance as argued by Aras et al. (2008). Whereas others show a relationship between firm size and CSR, but they were not able to find any positive or negative significant relationship between CSR and profitability. Nuryaman (2013) also conducted a study to investigate the relationship between CSR and corporate performance on companies listed on Indonesia Stock Exchange (ISE), he concluded that the company's profit is affected by disclosure of CSR, this effect is significant. Others argued that the level of CSRD depends upon various corporate characteristics (Rouf, 2011; Hossain et al., 2006; Porwal and Sharma, 1991). Based on practices and legislation in the shipping industry, they construct a Corporate Social Responsibility (CSR) disclosure index for listed shipping companies. Markov Chain Monte Carlo (MCMC) techniques have been used for Bayesian inference and they estimated the marginal effects of firm attributes on CSR disclosure for each firm. The study shows a positive association between CSR disclosure and financial performance for each firm in the international sample. Firm size, financial leverage and ownership structure are also correlated with CSR disclosure. The findings suggest that the most of these listed companies have integrated CSR practices into their strategic planning and operations (Drobetz et al., 2014). The current study's contribution is not limited to the Jordan context. However, it also extends to the wider aspect of CSRD research. Second, by investigating the correlation between CSRD and Financial Performance (FP), it extends prior research that links CSRD with some financial performance indicators; thus, the contribution of the current research is to add some argumentation to the growing body of literature about CSRD area in the developing countries. Finally, it is hoped that the benefit of the current study will cover various expected stakeholders like researchers, regulators and stockholders in Jordan industrial companies to comprehend the effect of CSR on the stock market and its impact on companies' financial performance. It is very important to notice that in the general procedure of the holy Quran the actions which are not qualified are Oppression or unjust (the Quranic term Dholm) (unjust), which in its general and intensive form means putting things in places other than their (own) places. The study used the accounting based financial performance measures. This measurement focuses on historical firm performance based on financial reporting data. Some measurements included in this group are Return on Assets (ROA), and Return on Equity (ROE), while the measurement which is not followed by the study is the measurement takes the market point of view, such as market share (stock) price. The study is categorized into five sections; Section one is the introduction, section two deals with literature review on meaning and other related components of corporate social responsibility disclosure from the employees' dimensions and environmental issues, section three explore methodology, section four shows results of data and section five dwell on conclusion and recommendations.

\section{Literature Review}

World Business Council for Sustainable Development (WBCSD) (1999) defined CSR as the morally continuous commitment of business towards a 
contribution rendered to the firms' employees in addition to their families and to local society as a whole, this commitment would be by providing them with adequate economic developments for improving the various aspects of their life. This definition by WBCSD has a moral concern and believes in societal issues like organizing a campaign for medical awareness at the urban areas. Most companies nowadays around the world encourage promoting Sustainable developments though their strategic plans. In brief, the concept of CSR comprehends various aspects of business activity extending from socioeconomic issues to the environmental benefits. Fredrick (1984) insists that the social responsibility of business includes the economic, legal, ethical and discretionary expectations that society has of organizations at a given point in time. Aaron and Patrick (2008) emphasized that there is no generally accepted definition of CSR, but according to them, on a general rule, CSR ranges from corporate commitments to ethical conduct, community involvement, employee relations and to philanthropic gestures by corporations in communities in which they operate. Wright and Ferris (1997); Husted and Allen (2000); McWilliams and Siegel (2000); Orlitzky et al. (2003); Husted and de Jesus Salazar (2006); Marom (2006); Moneva et al. (2007); Branco and Rodrigues (2008) have regarded CSR and CSR disclosure as positive indicators in improving financial performance for companies, these studies have examined the association between CSRD and companies financial performance. Most results have indicated that CSRD pushing business in a positive way, whilst other studies found a negative or mixed relation, but the growing demands for the most companies' stakeholders require more exploration of voluntary social activities and in order to improve financial performance, the nature of disclosure level is necessary. For making this point clear Brammer and Millington (2008) found that firms have high and low social disclosure levels will have higher financial performance, but Firm with poor social disclosure does best in the short run. Others argue that they made decisions based on criteria that include the relationship between CSR and CSRD with employee commitment that lead to boost organizational performance (Brammer et al., 2007; Rettab et al., 2009). Few studies explored this relation for companies in nascent (developing) countries (Hess et al., 2002; Toms, 2002; Hasseldine et al., 2005; Bebbington et al., 2008). It can be concluded that results of previous literature examining the relationship between Social Responsibility Accounting (SRA) with FP were different from one country to another, this diversification due to the diversity of business systems which are not identical among countries. Therefore, this study will shed lights on the relation between CSRD and FP in the industrial public share holding companies in Jordan. More specifically. There is no doubt that the Islamic religion as one of the heavenly religions urge of human beings to cooperate with each other and to serve the communities in which they are present, since the companies of manmade, it will have a great duty toward their employees and the community in general to serve as well as to maintain the environmental aspect in the best practice, because of its importance to the universe in general. There are various studies in the developed countries like Australia, the United States and the United Kingdom have focused on the definition of the relationship between disclosure of social responsibility and organizational performance, these studies concluded that there is a positive relationship between these variables (Peccei et al., 2005; Saleh et al., 2008; Zur et al., 2008; Rettab et al., 2009). There are few studies on this subject in the developing countries, these studies was interested about the relationship between social responsibility and organizational performance. However, most of the industrial companies in Jordan did not give the subject of social responsibility and disclosure any clear interest, lack of interest was caused due to the lack of motivations for companies to do this disclosure, in general, the literature review for both social responsibility accounting and disclosure show that there are a lot of stakeholders of this issue are trying to hold pressure on companies to raise the level of social responsibility and its disclosure dramatically, a lot of researchers study the issue of relationship between organizational performance in terms of financial performance, employees commitment and corporate reputation social responsibility disclosure, these studies have been divided into three categories: The first is the social responsibility disclosure studies that suggested a positive relationship between the two variables; most previous researches have considered CSR and CSRD as important pillars in enhancing financial performance for companies (Husted and Allen, 2000; Branco and Rodrigues, 2008; Muthuri et al., 2012), while the second type indicated a negative relationship (Brammer and Millington, 2008) the last type of such studies have pointed out that the relationship is mixed between CSRD and FP (McWilliams and Siegel, 2000).

The improvement of financial performance is not necessarily dependent variable on the level of disclosure. Muthuri et al. (2012) observe that a few researchers have examined strategic importance of CSR in the developing countries from the business perspective. Brammer and Millington (2008) argue that high and low levels of social responsibility disclosure have higher financial performance. Some researchers fall into the following 
categories; First; Companies that disclose their social activities in poorly way they perform well performance in the short run; while the companies that have good disclosure be well performed in the long run, however, some studies did not find any relationship between the CSRD and financial performance (McWilliams and Siegel, 2000). Second; there are number of studies that have found a positive correlation between corporate social responsibility and CSRD with the employees' indicator, which leads to improvement in organizational performance according to Brammer et al. (2007); Rettab et al. (2009). Despite the fact that a growing number of studies have searched various dimensions of CSRD, however, a few of them pointed out its influence on employees (Turker, 2009). Moreover, most studies have not dealt with any strategic Social Responsibility Disclosures (SRD) in developing countries from the aspect of relationship between CSR and CSRD in case of employees' commitment. While Rettab et al. (2009); Peccei et al. (2005) found a positive relationship between disclosure of information and the commitment of employees. Although many studies which emanated from companies in developed Western economies, there was no any study on companies in developing countries address this issue. But the most interested impetus on firms to examine CSRD relationship is to improve their business reputation. However, there are only a few studies described the relationship between CSRD and reputation of company; nonetheless, few studies looked at such relationship for companies in developing countries. Maskun (2013) investigated the effect of firm's leverage level, size and profitability toward the disclosure of Corporate Social Responsibility (CSR) for 45 companies registered in Indonesia Stock Exchange (IDX). The study used the sampling method, collections data only for 15 companies registered in the IDX which routinely publish their annual reports for the period 2009-2011. The study showed that leverage has a significant impact on the disclosure of corporate social responsibility, as well as company's size and profitability; both have the same significant effect which is in turn increase the society's welfare. Bebbington et al. (2008) have indicated that it seems reasonable the reports on disclosure of social responsibility can play a role in the reputation risk management. Toms (2002) suggests that firm's implementation, monitoring and disclosure of environmental policies in the annual reports make a significant contribution in the formation of good environmental reputation in the company. Hasseldine et al. (2005) tested the effect of both qualitative and quantitative disclosure on the company's reputation, their study revealed that quality of environmental disclosures have a stronger influence on the creation of good environmental reputation more than merely quantitative disclosure. Another study by Rettab et al. (2000) examined the relationship between corporate social responsibility and reputation of the company; they found a positive relationship between the two variables. But there was no study examined the relationship between the CSRD and the reputation of the company in developing countries. It can be noted that the results of previous studies have examined the relationship between corporate social responsibility and reputation of the company; these results vary from one country to another. Crane et al. (2005) Observed that the business systems vary from country to country. Thus, this study differs from previous studies, it is a complementary in some aspects for others and it attempts to find out the effect of leverage, profitability on different levels of Corporate Social Responsibility Disclosure in the developing countries like Jordan; which has an important site in the world, it is a secure country in a volatile region, all these positive indicators of Jordan due to the awareness of the leadership and people of Jordan. Behavior of the individual in Jordan stems from the Islamic religion instructions. According to Ali (1996) social institutions such as the family are respected by almost all individuals irrespective of their social backgrounds. Most of these institutions are using Islam to maintain their endurance and influence. It is clearly mentioned that Islam is a comprehensive religion which is not regulated life only as a means to asceticism but calls for humility and cooperation for happily life in this world, to attain satisfaction of God (Allah) in the worldly existence and afterlife. Adding to this, all aspects of life; whether social, political or other teachings were organized properly all time and place through its presence in the noble Qur'an, all these things have significant effect on individual behavior (Park and Lee, 2009; Kang et al., 2010). By going back to the core of the current study; Rettab et al. (2009) found a positive relationship between corporate social responsibility and organizational performance. It can be said that issue of corporate social responsibility has taken greater importance in various countries, as well as companies have to focus on Social Performance (CSP) in order to meet these applicable social responsibilities. However, it is not certain whether firms must devote to CSR-related specific activities, or whether Corporate Social Performance (CSP) can lead to better Corporate Financial Performance (CFP). According to Ullmann et al. (1985) the study of the relationship between (CSP) and (CFP) is not decisive. The main objective of this study is to address the increasing concern related to the relationship between Corporate Social Responsibility Disclosure (CSRD) and Financial Performance (FP) in the industrial 
public shareholding companies in Jordan. The motivation for this title lies in the shortage of this type of research in Jordan, despite the higher attentions about the importance of CSRD from stakeholders' perspective. Most firms in Jordan have shown their interests in CSRD as one of the most important alternatives to boost their business reputation. There was no adequate study of public share holding companies in Jordan examining this relationship, but the growing concern for social activities and financial performance for stakeholders have led these firms to become more commitment and responsible to their shareholders. Generally speaking, one can explain CSR as the conscious efforts by a business Firms to maximize its positive effect and minimize its negative effect on local community. Therefore, Jordanian companies in different sectors have adapted voluntary environmental initiatives in the local communities, but there is still a need for more strategic focus and longterm sustainability friendly technologies, the practice is still minimal. Few large companies like Arab Potash Company, Jordan Phosphate Mines try to demonstrate that they have positive impact on the environment. Both companies have undertaken some projects in the local community such as health centers, water projects, Town halls, internal concrete roads, electrification and cool rooms, worship places and have been put into use. Also these companies grant scholarship to educational institutions and university students annually. Jordan Bromine Company (JBC) (Private Firm Zone) also has implemented various activities according to its threeyear strategy that will cover Karak region in the southern part of Jordan, particularly the communities of the center (Qasaba), Ghor Safi and Ghor Mazra'a regions, examples of the activities implemented in this area are: The installation of four computer labs at public schools, Establishing a children's library at Save the Children Foundation in the Nuzha Area of Amman, organizing a campaign with governmental departments to fight anemia in children and mothers. Supporting various local community activities in Karak; providing donations to charities, civil defense and security Stations, in addition to a number of youth activities, which included the sponsorship of football clubs that appear in first league, in 2012. JBC funded, inaugurated the Bromine Forest in Kerak region and JBC conducted internship programs for students from local universities within the company to prepare them for the workforce and also provided them with important leadership and business skills .Although Jordan is considered one of the first countries in the Middle East to adopt a national environmental strategy; but many programs need to be implemented; like uncontrolled waste disposal, uncollected large quantities of waste, creating a proper management of solid wastes, enforcing regulations and implementing proper environmental awareness programs that will enhance the public understanding and achieve greater efficiency. But CSR strategies in Jordan at supporting sustainable community development projects need more concentration and attention. The annual reports of this sample of large Industrial companies in Jordan have not referred in a sufficient manner to any statement of environmental requirements towards operational activities and evidence of their fulfillment efficient use of resources, reducing quantity of waste generated and pollution (statement on a scale of recent years), design environmentally friendly products, developing environmentally friendly production processes. Companies tend to donate money assistance rather than more long-term causes like saving the environment or funding research to find solution for energy exploitation, natural resource depletion, land degradation, chemicals and waste are among Jordan's leading environmental interests. The main cause of Jordan's increasing air pollution is the rapidly increase in the number of automobiles in the country at $7 \%$, yearly according to Namrouqa (2009). This problem is expected to grow in the future, affecting national health significantly for these cases. In order to minimize the negative environmental issues, initiatives tax exemptions should be given to all those companies. Also, as per Namrouqa (2009) Environmental Analysis in Jordan has shown that collective damage caused by $\mathrm{CO}_{2}$ emissions from road vehicles in Jordan amounted to JD 130 million annually. In specific, heavy-duty automobiles, minivans, minibuses and light duty automobiles accounted for 60 to $90 \%$ of these gasses. However, passenger cars are the main cause of carbon monoxide and hydrocarbons, that is, $80 \%$ of such pollution. Electricity production, mining and cement creation were among the worst industrial polluter (Namrouqa, 2009). Regarding solid waste collection in Jordan, approximately $90 \%$ of urban solid waste are collected in addition to $70 \%$ of rural solid wastes, although frequently disposal them in landfalls. Disposal of dangerous Wastes such as medical wastes has no sufficient equipment. For example, roughly half of such waste is burned in old-fashioned incinerators and the remainder is dumped in open municipal open areas (Namrouqa, 2009). Jordanian governmental agencies and ministries like Ministry of Agriculture, Ministry of Water, Ministry of Environment and Transport regulatory commission have set pieces of many regulations and instructions like the Environmental Protection Law No. 52 of 2006 that is meant for the preservation of the environmental issues. This law doesn't require companies to conduct activities relating to the natural resources used, or to carry out social and 
environmental responsibility. By virtue of provision 13 of such law no.52 every corporation conducts activities that have negative impact on the environment is obliged to prepare an environmental impact assessment report for all its projects and submit such report to the Ministry of Environment to take the appropriate decision about this matter. On this regard, is this report is publicly disclosed? To what extent the penalties can be applied by force on the committed company. Companies in Jordan should understand that CSR has no any negative effect on shareholders' interests; it might raise the market value of shares up and give a reasonable reputation of the companies. CSR permits companies to promote their work through socially responsible practices, which will add value to the society as well as the company itself. Due to the advantages, although not immediately apparent of CSR to the firm itself, the issue should be reclassified as per UNDP (2011). Few studies have led to the development of a large number of methodologies for rating corporate social responsibility, such as, Trapani et al. (2014), which stated that over the last years, the interest in environmental services provided by forests has considerably grow, they found; from an economic point of view, the aim of providing these services, it is necessary the introduction of a convenient payment system or, in alternative, a situation in which positive externalities of landscape, in sync with other goods/services, are offered to consumers. They add, forest conservation and management assume a very important role, especially when public administration allocates decreasing funds to environment resources. In their paper, it has been analyzed how positive externalities provided from forest, by means of an appropriate payment system and considering the integration with surrounding area, can contribute to the value creation. I conclude that Measurement of CSR is a critical point since there is no agreed upon basis for measuring CSR activity up to date; the implementation of CSR might have higher costs without any significant financial impact received. The method of content analysis is applied to analyze 59 financial annual reports for 59 Jordanian industrial companies during 2013. I have chosen this sector for its importance, in addition to the availability of annual reports published in 2013; consequently, general research question to be answered and explained is; what is the effect of Leverage, size and profitability on Corporate Social Responsibility Disclosure in relation to employees disclosure (charity contributions, political donations, financial support for education, in-kind and financial support for public health, support for arts and culture, sponsoring of sports or recreational projects) and other employees' data, pension data, consultations with employees, employment of disabled individuals, value added statement, health and safety, shares ownership and the environmental side. I used the regression analysis; Ordinary Least Squares (OLS) for analyzing data. Various statistical tests were conducted to test the critical assumptions of the OLS regression namely; normality test, the assumption of linearity of the model parameters, assumption of homoscedasticity which entails variance or standard deviation of the dependent variable within the group to be equal and the assumption of independence of error terms. Finally, to test multicollinearity, the study applied correlation coefficient and diagnostics test for the model. However, there is a lack of specific studies related to the impact of corporate social responsibility disclosure, particularly in developing countries, no such study was carried out with special reference to Jordan.

\section{The Study Framework}

The present study has been conducted within the industrial firms working in Jordan. Total of (59) industrial firms were included in the study. All those firms were used as a framework for the sampling procedure of this study.

\section{Hypotheses Statements}

According to Raheman and Nasr (2007), Leverage means funds taken from outside parties like companies, capital market, money market and other financial institutions. A company's financial leverage is expected to be correlated with its level of CSRD. Companies with lower loans or leverage may face less pressure from their creditors, if the company tends to decrease CSRD expenses, it will disclose the minimum required items to cope with the law requirements and to avoid stakeholders' claims. Accordingly, the first two hypotheses are:

Ha1: Firm's financial leverage (LEV.) has a negative impact on CSRD level towards the employees' dimension.

Ha2: Firm's financial leverage (LEV.) has a negative impact on CSRD level towards the environmental dimension.

It is expected that similar arguments apply to the impact of CSR disclosure and a firm's profitability. When the profitability is high, a firm is more likely to possess the economic ability to disclose CSR information; because profitability is a healthy indicator encourages management to disclose more items in its financial reports. ROA is a ratio that measures how efficiently a company can manage its assets to produce profits during a period. Based on this argument; I can test the second two hypotheses: 
Ha3: Firm's ROA has a positive impact on CSRD level towards the employees' dimension.

Ha4: Firm's ROA has a positive impact on CSRD level towards the environmental dimension.

Convincing firms' shareholders with a high rate of return on equity, will motivate management to disclose more information of CRS to assure that the firm's financial flexibility and profitability are sound, based on this argument, this ratio is a measure of profitability of stockholders' investments. It shows net income as percentage of shareholder equity. The third two hypotheses are:

Ha5: Firm's ROE has a negative impact on CSRD level towards the employees' dimension.

Ha6: Firm's ROE has a positive impact on CSRD level towards the environmental dimension.

There isn't one single measure for the size of company; Number of employees, is a powerful indicator, but a proper evaluation of size in this study would be considered as total asset values as per the statement of financial position. Size is measured as the natural logarithm of year-end total assets. Larger firms encounter more public pressure because of their effect on the community. Thus, they have greater incentive to disclose CSR activities. Studies show that firm size has a positive impact on the level and the quality of CSR disclosure, according to Reverte (2009).

Based on this argument; I test the following two hypotheses:

Ha7: Firm's size has a positive impact on the level of its corporate social responsibility disclosure towards the employees' dimension.

Ha8: Firm's size has a positive impact on the level of its corporate social responsibility disclosure towards the environmental dimension.

\section{Methodology}

\section{Data Collection Method}

The research was conducted using primary data, which are analytical in nature. The study data collection were taken from the annual reports of 59 public shareholding industrial companies listed at Amman Stock exchange out of 73 , by focusing on data related to the employees and other environmental activities conducted by these firms for the year of 2013. In order to determine the Impact of financial leverage (debt/equity), profitability; ROA, ROE and size on corporate social responsibilities disclosure levels (CSRD) and to test hypotheses; some statistical measures were used; Correlation and regression analyses. For purpose of analysis and interpretation of findings, the current study uses content analysis technique, to analyze the CSRD for each category selecting a "yes/no" or $(1,0)$ scoring methodology. If the information is available for questionable item, this item will gain a score of 1 , whereas a score of 0 will be given if no information for this item. In order to quantify the items, the aggregate score for each company is determined by summing up scores of 1 according to Sharif and Rashid (2014). Calculating the final disclosure score indices for each category is done using the formulas 1 and 2 as follows:

Formula 1 is applied to Calculate Categories related to employees (CSRD1) Information from Companies' Annual Reports of:

$\sum_{t=1}^{m j} E M D=$ Employees' data + Pensions' data + Consultations with employees + Employment of disabled individuals + Value added statement + Health and safety + Share ownership + Equal opportunities + ....etc.

$$
X 1=\sum_{t=1}^{m j} \frac{x t}{N}
$$

Where:

$$
\begin{aligned}
\sum_{t=1}^{m j} E M D= & \text { Total scales of employee disclosure } \\
X I & \text { Summing of disclosure score indexes for } \\
& \text { each category } \\
= & 1 \text { if the indicator } \tau \text { is disclosed and } 0 \\
& \text { otherwise } \\
= & \text { Maximum number of relevant items a } \\
& \text { company may disclose }
\end{aligned}
$$

From a total population of 73 industrial annual reports were obtained for each of company only 59 companies were relevant during the year.

Formula 2 is used to Calculate Categories related to environmental activities (CSRD2) Information from Annual Reports of Companies in Jordan.

$\sum_{t=1}^{m j} E M D=$ Environment expenditure + Pollution abatement + Environment preservation + Recycling programs ++ etc:

$$
X 1=\sum_{t=1}^{m j} \frac{x t}{N}
$$

\section{Where:}

$\sum_{t=1}^{m j} E M D=$ Total scales of Environmental disclosed items

$X I=$ Final disclosure score indexes for each category

$X \tau=1$ if the indicator $\tau$ is disclosed and 0 otherwise

$N \quad=$ The maximum number of relevant items a company may disclose 


\section{Study Model}

To test hypotheses, the following model intended to be employed in this study:

$$
\mathrm{Y}=\alpha+\beta 1 \mathrm{x}_{1}+\beta 2 \mathrm{x}_{2}+\beta 3 \mathrm{x}_{3}+\beta 4 \mathrm{x}_{4}+\mathrm{e}
$$

Where, y refers to CSRD1, or CSRD 2which is a dummy variable that could be either 1 or $0, \beta(1-4)$ refers to the coefficients for independent variables and $\alpha$ is the constant value. $x_{1}$ refers to Leverage, $x_{2}$ refers to ROA, $x_{3}$ refers to ROE , $x_{4}$, refers to size of the company as based on the total assets used in this research in billions with Jordanian Dinar (JD) unit and ę refers to stochastic term.

\section{Results}

\section{Descriptive Analysis}

However, Table 1 presents the number and percentages of companies whose disclosure Score is within the specified range from [0.00-54.20\%]. These indices present the areas that annual report may disclose for the study sample in relation to some specific items despite the fact that says: Ignoring employees concerns might not be affected by profitability, or can have a serious negative or positive impact on CSR disclosure and the same for environmental activities. Therefore, most of companies out of study sample have disclosed some of their employees data by the annual reports; (Gender, Age, Qualifications and Numbers) with a percentage of (54.20\%), Hajj or Umrah (Holly travels to Mecca and Medina) $(45.80 \%)$, in addition to $(42.40 \%)$ for training plans. The lowest percentage $(30.50 \%)$ is for Share ownership, Rewards and Remuneration to employees, Participations and Sponsorship of sporting events.

Disclosing of environmental activities levels in the annual reports are fluctuated from 23.7 to $35.6 \%$, which is not expected if compared with the employees", disclosures. Based on my study's analysis shown in Table 1 that presents CSRD subcategories of CSR disclosure score, I can find that $(36.8 \%)$ of the companies listed on the Amman Stock Exchange report CSR relating to employees in their annual reports and $(30.80 \%)$ relating to environmental activities, this means CSR reporting to be weakly implemented and the majority of these companies don't report CSR during the sample period.

Descriptive statistics analysis is used to calculate Mean, Median and Standard deviation, OLS and Pearson correlation are used to test if there is an impact exists between CSRD and one of the Leverage, ROA, ROE and Size. The outcomes in Table 2 indicate that size has a mean value of 16.657 with maximum and minimum value of (20.830) (14.230) respectively. ROA is observed with a mean value of $(-0.217)$. The mean value of ROE is (-2.698) and (38.216) for the Leverage.
The findings in Table 2 reveal that descriptive statistics for these variables covered in this study. Data obtained from the annual reports can be ranked as first for debt ratio (mean $=38.216)$; this shows that about $(38.2 \%)$ of the companies in the study have a funds financed by debt, then the second as for size; Mean $=(16.657)$. The average index for the dependent variable (CSRD1) in this study is $(0.483)$. This average illustrates higher disclosure for Employees' personal characteristics (CSRD1). This average is more than (CSRD2) as a dependent variable (0.297), Jarque-Bera statistic stood at (5.615) and the p-value of (0.060) indicates that the data for only the CSRD1 will not satisfy normality criterion at $(5 \%)$ level of significance $(\mathrm{p}>0.05)$. The small standard deviation value of (1.414) doesn't indicate considerable dispersion from the Mean. For the dependent variables, Jarque-Bera statistic $P$.value were less than (5\%) for all independent variables except for Debt ratio (LEV.) which is $(2.735)$, this indicates that the data is normally distributed at $(5 \%)$ level of significance $(p<0.05)$ for all independent variables except Leverage, this means that the normal distribution fails the normality only for this variable. The large standard deviation value for most of variables indicates considerable dispersion from the mean. Then, I can suggest from Table 2 that the average financial performance of the firms is very low.

\section{Correlation and Regression Analysis}

Pearson correlation coefficient is applied to test the relationship between CSRD and company's profitability in terms of financial performance; Return on Asset (ROA), Return on Equity (ROE), Size and Debt ratio (LEV). This study attempts to use the Pearson correlation analysis method (Charles-Henri and Stéphane, 2002; McWilliams et al., 2006; Hull and Rothenberg, 2008) and regression analysis (Hull and Rothenberg, 2008). The two preliminary indications that are demonstrated in Table 3 have significantly association with CSRD1; size and ROA. Employees' disclosures have a positive correlation coefficient of (0.264) in relation to Company size, with a significant level which is $(0.043)$ less than $(5 \%)$. This means when company size increases, CSRD1 also increases. Similarly, ROA has a significant weak positive correlation with CSRD1 (0.364); while ROE and Leverage (LEV.) have insignificant correlations at the level of $(5 \%)$. The correlation coefficient results show that none of the variables are strongly correlated. Also this indicates that the problem of multicollinearity is unlikely and hence the variables are appropriate for conducting regression analysis. Only leverage shows consistently negative insignificant correlation with CSRD2, the other variables; ROA, ROE and size have positive correlation, only ROA is significant. 
Table 1. CSRD subcategories of CSR disclosure score

\begin{tabular}{|c|c|c|c|}
\hline No. & Employees' disclosure & Frequency & $*(\%)$ \\
\hline I1 & Employees' personal characteristics & 32 & 54.20 \\
\hline $\mathrm{I} 2$ & Training plans & 25 & 42.40 \\
\hline $\mathrm{I} 3$ & Pension, remuneration data & 20 & 33.90 \\
\hline $\mathrm{I} 4$ & Consultation with employees and workers & 21 & 35.60 \\
\hline I5 & Employment of disabled individuals & 20 & 33.90 \\
\hline I6 & Welfare Journeys & 20 & 33.90 \\
\hline I7 & Health and safety & 20 & 33.90 \\
\hline I8 & Share ownership & 18 & 30.50 \\
\hline I9 & Rewards and Remuneration to employees & 18 & 30.50 \\
\hline $\mathrm{I} 10$ & Participations & 18 & 30.50 \\
\hline I11 & Sponsorship of sporting events & 18 & 30.50 \\
\hline $\mathrm{I} 12$ & Canteen & 25 & 42.40 \\
\hline $\mathrm{I} 13$ & Common Room for smoking & 19 & 32.20 \\
\hline I14 & Lighting, ventilation, temperature and noise levels & 25 & 42.40 \\
\hline $\mathrm{I} 15$ & Information panels/newsletter/bulletins & 21 & 35.60 \\
\hline I16 & Internal meetings & 21 & 35.60 \\
\hline I17 & voluntary activities & 25 & 42.40 \\
\hline I18 & Internships and study grants & 22 & 37.30 \\
\hline I19 & Employee motivation & 20 & 33.90 \\
\hline $\mathrm{I} 20$ & Hajj or Umrah (Holly travels to Mecca and Madina) & 27 & 45.80 \\
\hline $\mathrm{I} 21$ & Rewarding place to work & 21 & 35.60 \\
\hline $\mathrm{I} 22$ & Proper Working Places for Mums & 21 & 35.60 \\
\hline \multirow[t]{2}{*}{$\mathrm{I} 23$} & Supporting well-being & 20 & 33.90 \\
\hline & Average of annual reports CSRD1 level & & 36.80 \\
\hline \multicolumn{4}{|c|}{ Environmental areas } \\
\hline $\mathrm{I} 24$ & Environment expenditures (promoting, training) & 21 & 35.60 \\
\hline $\mathrm{I} 25$ & Recycling programs & 14 & 23.70 \\
\hline $\mathrm{I} 26$ & Planting of trees & 19 & 32.20 \\
\hline \multirow[t]{2}{*}{$\mathrm{I} 27$} & Friendly equipment and facilities & 17 & 28.80 \\
\hline & Average of annual reports CSRD2 level & & 30.80 \\
\hline
\end{tabular}

$\%$ disclosing of companies as a percentage of samples which is (59)

Table 2. Descriptive statistics for all variables

\begin{tabular}{|c|c|c|c|c|c|c|}
\hline & CSRD1 & CSRD2 & LEV. & $\mathrm{ROA}$ & ROE & SIZE \\
\hline Mean & 0.368 & 0.297 & 38.216 & -0.217 & -2.698 & 16.657 \\
\hline Median & 0.304 & 0.250 & 35.990 & 2.970 & 1.970 & 16.530 \\
\hline Maximum & 1.000 & 1.000 & 107.110 & 15.720 & 89.070 & 20.830 \\
\hline Minimum & 0.000 & 0.000 & 0.490 & -96.490 & -178.040 & 14.230 \\
\hline Std. Dev. & 0.263 & 0.269 & 23.304 & 14.923 & 30.448 & 1.414 \\
\hline Jarque-Bera & 5.615 & 6.319 & 2.735 & 2120.312 & 940.639 & 6.338 \\
\hline Probability & 0.060 & 0.042 & 0.255 & 0.000 & 0.000 & 0.042 \\
\hline Observation & 59.000 & 59.000 & 59.000 & 59.000 & 59.000 & 59.000 \\
\hline
\end{tabular}

Table 3. Correlation coefficients between levels of CSRD with profitability, size

\begin{tabular}{|c|c|c|c|c|c|c|c|c|c|c|c|}
\hline \multirow[b]{2}{*}{ Size } & \multirow{2}{*}{\begin{tabular}{l} 
Size \\
\hdashline 1
\end{tabular}} & \multicolumn{2}{|c|}{ ROA } & \multicolumn{2}{|l|}{ ROE } & \multicolumn{2}{|l|}{ LEV. } & \multicolumn{2}{|l|}{ CSRD1 } & \multicolumn{2}{|l|}{ CSRD2 } \\
\hline & & 0 & -1 & -0.04 & -0.76 & 0.126 & -0.34 & $0.264^{*}$ & -0.04 & 0.248 & -0.059 \\
\hline ROA & & 1 & & $0.863^{* *}$ & 0 & -0.08 & -0.55 & $0.364^{* *}$ & -0.01 & $0.268^{*}$ & -0.040 \\
\hline ROE & & & & 1 & & -0.03 & -0.8 & 0.253 & -0.05 & 0.238 & -0.069 \\
\hline LEV. & & & & & & 1 & & -0.24 & -0.06 & -0.25 & -0.054 \\
\hline CSRD1 & & & & & & & & 1 & & $0.369^{* *}$ & -0.004 \\
\hline CSRD2 & & & & & & & & & & 1 & \\
\hline
\end{tabular}

* Correlation is significant at the 0.05 level (2-tailed)

** Correlation is significant at the 0.01 level (2-tailed) 


\section{Effect Model and Hypotheses Testing}

Ordinary least squares regression (OLS) test conducted using E. views 7.0 can be presented in Table 4; the white heteroskedasticity-consistent standard error is used to control for possible heteroskedasticity in the model. The $\mathrm{R}^{2}$ coefficient of determination for CSRD1 is 0.2720 , which indicates that the model explains about $27.20 \%$ of the systematic variations in the dependent variable. The Adjusted $\mathrm{R}^{(2)}$ which controls for the effect of inclusion of successive explanatory variable son the degrees of freedom was 0.2128 . The F-stat value of 5.0437 and the associated p-value of $5 \%$ is 0.0016 indicates that the hypothesis of a joint statistical significance of the model cannot be rejected as $5 \%$ and the linearized specification of the model is not inappropriate. Leverage result is significantly related to CSR disclosure (CSRD) by companies as indicated by its slope coefficient value of- 0.0028 and $p$-value of 0.0399 for CSRD1, slope coefficient value of -0.0031 , p-value of 0.0312 for CSRD2 which is less than the critical pvalue for each one of the two dimensions at $5 \%$ level $(p<5 \%)$, thereby leading to the acceptance of the alternative hypothesesHa1:“ Firm's financial leverage (LEV) has a negative impact on CSRD1 level towards the employees' dimension" and Ha2: "Firm's financial leverage (LEV) has a negative impact on CSRD2 level towards the environmental dimension". Companies listed on Amman Stock Exchange (ASE) with high leverage ratio tend to disclose less CSRD1 and CSRD2 than companies with a low leverage ratio. Likewise, this is consistent similar with the study done by Maskun (2013); Drobetz et al. (2014) who found that leverage ratio has significant impact towards the scale of voluntary disclosure which found a negative association between leverage and the level of voluntary disclosure. The result showed opposed change in the direction with dependent variables. So, bigger leverage would increase the disclosure of Social Responsibility (Ha1, Ha2) for both employees and environmental dimensions respectively with the assumption that other variables are constant. The results above explain that industrial companies has quite high leverage ratio so the obligation to disclose is not large. I can argue that the higher the leverage, the bigger the possibility that the company would violate the debt contract. Thus, the leverage level of a company has significant and negative impact toward the disclosure of corporate social responsibility for both dimensions. For this, I support the first two alternative hypotheses, for the next two significant variables; ROA and ROE. I think ROA is superior to ROE for capturing the joint effects on CSRD indices. In fact, ROA generally seems to be a better metric of operating performance than ROE (Drobetz et al., 2014). It explicitly takes into account the assets used to support business activities and it determines whether a firm is able to generate an adequate return on these assets rather than simply showing a return on equity (Hagel and Brown, 2010). ROA is positively and significantly related to CSRD1 by companies as indicated by its slope coefficient value of 0.0085 and $p$-value of 0.0425 which is less than the critical $p$-value of $5 \%$ level $(\mathrm{p}<0.05)$, thereby leading to the supporting of hypothesis Ha3: "Firm's ROA has a positive impact on CSRD1 level towards the employees' dimension". This showed the change in same direction with dependent variables. So, the bigger the Profitability expressed by (ROA); the bigger the Disclosure of Social Responsibility towards employees' dimension. This study is similar to study done by Maskun (2013). Similarly, ROA is positively associated with CSRD2 as indicated by its coefficient value of 0.0028 and insignificant p-value of 0.4960 , thereby leading to the rejection of the hypothesis Ha4: "Firm's ROA has a positive impact on CSRD level towards the environmental dimension". This result is consistent with McWilliams and Siegel (2000); Nuryaman (2013).

The recent research has made a significant contribution to my understanding of the impact of leverage, ROA, ROE and company size on CSR disclosures in relation to non-financial factors to employees in industrial companies in Jordan in addition to environmental ones. Return on Equity (ROE) was negatively associated (-0.0014) and insignificantly $(0.4960)$ related to the extent of employees disclosure by companies at $5 \%$ level $(\mathrm{p}<0.05)$. Hence, I reject the alternative hypothesis Ha5; Firm's ROE has a negative impact on CSRD level towards the employees' dimension. This suggests that more ROE companies are less likely to increase the extent of their corporate social disclosure and less ROE companies are more likely to reduce the extent of their CSR disclosures in relation to employees' dimension. In relation to the environmental dimension, "ROE was positively associated $(0.0010)$ and insignificantly (0.6549) related to the extent of environmental disclosure by companies at $5 \%$ level $(p>0.05)$. Therefore, I reject the alternative hypothesis Ha6; "Firm's ROE has a positive impact on CSRD level towards the environmental dimension". Because this impact is however observed to be insignificant at 5\% hypothesis is not supported. Further, company size is a good predictor to the CSRD practice towards employee. The bigger company size will affect to the more comprehensive CSR activities. This point of view was derived from the perception that the implementation of CSR might have high costs without any significant financial impact received, so the initiation or cancellation of CSRD may depend upon the availability of funds. The evaluation of the slope coefficients of the explanatory variables reveals the existence of positive relationship between CSR Disclosure (CSRD) and Firm Size as depicted by the slope coefficient of 0.0537 . The 
result is however significant as p-value (0.0171) which is less than the critical p-value of 0.05 ; thereby, leading to the supporting of the hypothesis Ha7: "Firm's size has a positive impact on the level of its corporate social responsibility disclosure towards the employees' dimension". This Regression Coefficients of Company Size has positive coefficient sign. This showed the same direction of change with dependent variables. So, bigger Company Size would increase the Disclosure of Corporate Social Responsibility Disclosure towards the employees' dimension, with assumption that other variables are constant. This study result is similar to Suwaidan (2004); Drobetz et al. (2014) that finds the firm size is expected to be positively associated with the extent of social responsibility disclosures. But is opposed to (Hossain et al., 2006). Consequently, the alternative hypothesis; Ha8: Firm's size has a positive impact on the level of its corporate social responsibility disclosure towards the environmental dimension. The slope coefficient is $(0.0543)$, the impact is significance (0.0235) which means the hypothesis is supported. Firm size has a positive impact on the level of its corporate social responsibility disclosure towards the environmental dimension, from this result, I can point out that companies even though evaluate the cost-benefits of such disclosures, there is considerable variability in the amount of social activities disclosed in corporate annual reports towards its environment. The bigger the amount of assets, the bigger disclosure of the company CSRD 1 or/and CSRD 2. Having a big amount of assets may facilitate the company in funding. Moreover, firm size has a positive impact on the level of its corporate social responsibility disclosure. Finally, the Durbin-Watson value of 1.7908 indicates that stochastic dependence between successive units of the error term is unlikely in the model. The value of Durbin-Watson must be larger than 2 but smaller than
$4(2<\mathrm{DW}<4)$ as indication free from autocorrelation problem. Regression model is free from this problem. Lastly, multicollinearity test is done by checking the value of Variance Inflation Factor (VIF). The VIF must be no more than 10 . Thus, the model indicates nomulticollinearity problem as shown in Table 4.

\section{Diagnostics Test for the Model}

The following tests were conducted for the model to ensure that basic ordinary least squares assumptions have not been violated and that the estimates resulting from the model were the best, linear unbiased estimates of the population parameters. The tests were Autoregressive Conditional Heteroskedasticity (ARCH) for heteroskedasticity test, the LM test for autocorrelation and the Ramsey reset test for the model specification. Tables 5 and 6 reveal that p-value for both F-statistics and the observed R-squared were $0.447,0.427$ and $0.941,3.845$ respectively using residual lag length of 2 . The values are greater than the critical value of 0.05 at $5 \%$ significance level. This shows that there is no evidence for the presence of heteroskedasticity. Hence there is violation of the constant variance assumption of the ordinary least squares. The same result is applied for Environmental Issues: CSRD2, in which all p-values for both f-statistics and the observed R-squared were more than 0.05 .

Breusch-Godfrey correlation LM tests for the presence of autocorrelation presented in Table 7 . The result reveals that P-value of the F-statistics and the observed R-squared were 0.226 and 0.182 respectively using a residual lag length of three. When compared to the critical value of 0.05 , the P-values are noticed to be higher and this shows non-existence of autocorrelation. Hence, the estimates of the regression follow the non-violation of zero covariance assumption of the ordinary least squares and the estimates are free from any bias.

Table 4. Regression analysis by themes

\begin{tabular}{|c|c|c|c|c|}
\hline $\begin{array}{l}F(\text { ratio })=5.0437 \\
\text { Variable }\end{array}$ & Coefficient & $\begin{array}{l}\mathrm{R}^{(2)}=0.2720 \\
\text { VIF }\end{array}$ & $\begin{array}{l}\text { Adjusted } \mathrm{R}^{(2)}=0.2128 \\
\text { t-Statistic }\end{array}$ & $\begin{array}{l}\text { D.W }=1.7908 \\
\text { Prob. }\end{array}$ \\
\hline \multicolumn{5}{|c|}{ *Employees Issues: CSRD1 } \\
\hline Constant & -0.4205 & & -1.1647 & 0.2493 \\
\hline LEVERAGE & -0.0028 & 1.029 & -2.1053 & 0.0399 \\
\hline ROA & 0.0085 & 3.974 & 2.0781 & 0.0425 \\
\hline ROE & -0.0014 & 3.958 & -0.6855 & 0.496 \\
\hline SIZE & 0.0537 & 1.024 & 2.4605 & 0.0171 \\
\hline \multicolumn{5}{|c|}{ **Environmental Issues: CSRD2 } \\
\hline $\mathrm{F}($ ratio $)=3.5073$ & $\mathrm{R}^{(2)}=0.0 .2062$ & & Adjusted $\mathrm{R}^{(2)}=0.1474$ & D.W $=2.3549$ \\
\hline Variable & Coefficient & VIF & t-Statistic & Prob. \\
\hline Constant & -0.4855 & & -1.2586 & 0.2136 \\
\hline LEVERAGE & -0.0031 & 1.029 & -2.2116 & 0.0312 \\
\hline ROA & 0.0028 & 3.974 & 0.6336 & 0.529 \\
\hline ROE & 0.001 & 3.958 & 0.4495 & 0.6549 \\
\hline SIZE & 0.0543 & 1.024 & 2.332 & 0.0235 \\
\hline
\end{tabular}

*CSRD1 $=-0.4205--0.0028 *$ LEV.$+0.0085 *$ ROA $-0.0014 *$ ROE $+0.0537 *$ SIZE

$* *$ CSRD2 $=--0.4855-0.0031 *$ LEV.$+0.0028 *$ ROA $+0.0010 *$ ROE $+0.0543 *$ SIZE 
Table 5. Heteroskedasticity: Breusch-pagan-Godfrey test by themes

*Employees Issues: CSRD1

\begin{tabular}{llll}
\hline F-statistic & 0.9410 & Prob. F $(4,54)$ & 0.4470 \\
Obs.*R-squared & 3.8450 & Prob. Chi-Square (4) & 0.4270 \\
Scaled explained SS & 3.6480 & Prob. Chi-Square (4) & 0.4560 \\
**Environmental issues: CSRD2 & & & \\
F-statistic & 1.8706 & Prob. F $(4,54)$ & 0.1289 \\
Obs.*R-squared & 7.1802 & Prob. Chi-Square (4) & 0.1267 \\
Scaled explained SS & 5.7579 & Prob. Chi-Square (4) & 0.2180 \\
\hline
\end{tabular}

Table 6. Autoregressive heteroskedasticity test: ARCH

*Employees issues: CSRD1

\begin{tabular}{llll}
\hline F-statistic & 0.3742 & Prob. F $(1,56)$ & 0.5432 \\
Obs. *R-squared & 0.385 & Prob. Chi-Square (1) & 0.535 \\
**Environmental issues: CSRD2 & & & \\
F-statistic & 0.7374 & Prob. F $(1,56)$ & 0.3942 \\
Obs.*R-squared & 0.7538 & Prob. Chi-Square (1) & 0.3853 \\
\hline
\end{tabular}

Table 7. Breusch-Godfrey serial correlation LM test

\begin{tabular}{lllr}
\hline *Employees Issues: CSRD1 & & & \\
\hline F-statistic & 1.430928 & Prob. F $(2,52)$ & 0.2483 \\
Obs. ${ }^{* R-s q u a r e d}$ & 3.077722 & Prob. Chi-Square (2) & 0.2146 \\
**Environmental Issues: CSRD2 & & & \\
F-statistic & 2.039730 & Prob. F $(2,52)$ & 0.1403 \\
Obs. $*$ R-squared & 4.291912 & Prob. Chi-Square (2) & 0.1170 \\
\hline
\end{tabular}

\section{Conclusions and Recommendations}

One of the limitation in this study is that data only for one year. The results may differ across different years if multiple years are considered for analysis; the second is the use of only industrial companies as a sample of the study. So, the results may not extend across all companies in the Hashemite Kingdom of Jordan. Measurement of CSR is a critical point since there is no agreed upon basis for measuring CSR activity up to date. CSRD is a representation of company's 'good attitude' to employees because those things are recognized as a good management practice. Similarly, company will try to fulfill all employees' needs and all environmental requirements toward the society and give the satisfaction to its employees and community. So the management will develop new capability to manage firm resources effectively and efficiently. Then, CSRD can bring a competitive advantage because it will contribute to company's strong financial performance. I studied comprehensive data of 59 listed industrial companies during 2013 sample period by applying items suggested in previous literature to measure CSR Drobetz et al. (2014); Maskun (2013) and many others. I approximated CSRD for employees and environmental dimensions for each company in my study's sample and I assessed the sign and the statistical significance of the relationships with various company characteristics.

Most importantly, I documented a positive significant impact of size of the company on both types of CSRD dimensions; employees and the environment. I found a negative significant impact of leverage on CSRD (both employees and environment) dimensions for the industrial companies in my study sample. However, I also showed a positive significant impact of operating performance as measured by return on assets for the sample on CSRD towards employees dimension only, the impact of ROA on CSRD towards the environmental dimension is positive and insignificant. The impact of ROE is negative insignificant on CSRD towards employees. Consequently, the study showed Positive insignificant impact of ROE on CSRD towards environmental dimension. This study identified the impact of CSRD in relation to employees in Jordanian society. This means that CSR contributes to a way of living a healthy life in the community. Corporate Social Responsibility is not the primary objective of the companies in Jordan, this objective occupy the second rank after the Profit which is in turn formulates the major and primary objective of every firm. Industrial Public Shareholding Companies in Jordan starts in formulating corporate social responsibility policy for the sector. This policy is also made to comply with the directions of regulatory authorities and governmental policies. Corporate social responsibility should be applied by the firm as social obligations business concerns owe their employees and the surrounded environment, for this cause; CSR should be included in the annual reports and enforced on the firms accordingly. To some extent, the level of commitment for disclosing social information in 
relation to employees or to the environment was not as I expect, this low level is due to lack of information directed to these companies by Government and other regulatory bodies in improving the quality of the company performance through what is offered to the employees, such as training, bonuses, advances to employees and others. The study has provided insight into the effect of corporate social disclosure. In this regard, there is a need for regulatory agencies to develop a CSR reporting framework that focuses considerably on utilizing firm employees' information and providing corporate incentives for CSR disclosed and penalties for nondisclosure. This research only focuses on annual reports, future research should use other mass mechanisms, such as advertising, interim reports, promotional leaflets, websites and separate reports for society, environment and environmental communication capacities. However, these results should be interpreted in light of some limitations. Regression model violates normality assumption. Further, measurement of CSRD activities is based on management desire. Lastly, this research only examines the effect for one year time period. Therefore, future research may take longer periods to capture a more comprehensive picture about the association between CSRD and other corporate financial performance. From the environmental issues point of view, the results, firstly suggest that CSRD should be considered as a part from company's business strategy since CSR has been affected by some financial operating indicators. Secondly, the measurement of CSR activities by the company is totally based on the size of disclosure that should be fully sustained. Companies should focus on the measurement and supporting of corporate environmental issues, like the supporting for actions designed to protect the environment at the source through purchasing equipment that might be reused or/and that contain recycled materials. For encouraging the companies implementing environmental practice initiatives, tax exemptions should be given to the cooperative ones.

\section{Acknowledgement}

I am sincerely grateful to my university, Alzaytoonah University of Jordan for funding this work.

\section{Author Contribution}

The sole author designed, analyzed and interpreted and prepared the manuscript.

\section{Ethics}

This article is original and unpublished elsewhere. I confirm that there are no ethical issues involved.

\section{References}

Aaron, K.K. and J.M. Patrick, 2008. The failure of corporate social responsibility in the Niger Delta: Toward re-interpretation. Proceedings of the International Conference on the Nigerian State, Oil Industry and the Niger Delta, (IND' 08), Harey Publications Company, Port-Harcourt, pp: 435-435.

Ali, A. 1996. Organizational development in the Arab World. J. Manage. Develop., 15: 4-21.

DOI: $10.1108 / 02621719610117213$

Aras, G., A. Aybars and O. Kutlu, 2008. Managing corporate performance: Investigating the relationship between corporate social responsibility and financial performance in emerging markets. Int. J. Productivity Performance Manage., 59: 229-254. DOI: $10.1108 / 17410401011023573$

Bebbington, J., C. Larrinaga and J.M. Moneva, 2008. Corporate social reporting and reputation risk management. Account. Audit. Accountability J., 21: 337-361. DOI: 10.1108/09513570810863932

Brammer, S. and A. Millington, 2008. Does it pay to be different? An analysis of the relationship between corporate social and financial performance. Strategic Manage. J., 29: 1325-43. DOI: 10.1002/smj.714

Brammer, S., A. Millington and B. Rayton, 2007. The contribution of corporate social responsibility to organizational commitment. Int. J. Hum. Resource Manage., 18: 1701-19.

DOI: $10.1080 / 09585190701570866$

Branco, M.C. and L.L. Rodrigues, 2008. Factors influencing social responsibility disclosure by Portuguese companies. J. Bus. Ethics, 83: 685-701. DOI: $10.1007 / \mathrm{s} 10551-007-9658-\mathrm{z}$

Brine, M., R. Brown and G. Hackett, 2006. Corporate social responsibility and financial performance in the Australian context. Australian Treasury.

Charles-Henri, D. and T. Stéphane, 2002. The corporate social performance-financial performance link: Evidence from France. Department of Accounting, University of Bordeaux.

Crane, A., C. Driver, J. Kaler, M. Parker and J. Parkinson et al., 2005. Stakeholder democracy: towards a multi-disciplinary view. Bus. Ethics: A Eur. Rev., 14: 67-75. DOI: $10.1111 / \mathrm{j} .1467-8608.2005 .00387 . \mathrm{x}$

Drobetz, W., A. Merikas, A. Merika and M.G. Tsionas, 2014. Corporate social responsibility disclosure: The case of international shipping. Trans. Rese. Part E, 71: 18-44. DOI: 10.1016/j.tre.2014.08.006

Fredrick, R.E., 1984. Strategic management: A stakeholder approach. Adv. Strategic Manage., 1: 31-60.

Hagel, J. and J.S. Brown, 2010. The best way to measure company performance. Harvard Business Publishing. 
Hasseldine, J., A.I. Salama and J.S. Toms, 2005. Quantity versus quality: The impact of environmental disclosures on the reputations of UK Plcs. Brit. Account. Rev., 37: 231-248.

DOI: $10.1016 /$ j.bar.2004.10.003

Hess, D., N. Rogovsky and T.W. Dunfee, 2002. The next wave of corporate community involvement: Corporate social initiatives. California Manage. Rev., 44: 110-125. DOI: 10.2307/41166125

Hossain, M., K. Islam and J. Andrew, 2006. Corporate social and environmental disclosure in developing countries: Evidence from Bangladesh.

Hull, C.E. and S. Rothenberg, 2008. Firm performance: The interactions of corporate social performance with innovation and industry differentiation. Strategic Manage. J., 29: 781-789. DOI: $10.1002 /$ smj.675

Husted, B.W. and D.B. Allen, 2000. Is it ethical to use ethics as strategy? J. Bus. Ethics, 27: 21-31. DOI: 10.1023/A:1006422704548

Husted, B.W. and J. de Jesus Salazar, 2006. Taking Friedman seriously: Maximizing profits and social performance. J. Manage. Studies-Oxford, 43: 75-86. DOI: $10.1111 / \mathrm{j} .1467-6486.2006 .00583 . \mathrm{x}$

Kang, K.H., S. Lee and C. Huh, 2010. Impacts of positive and negative corporate social responsibility activities on company performance in the hospitality industry. Int. J. Hospitality Manage., 29: 72-82. DOI: $10.1016 /$ j.ijhm.2009.05.006

Marom, I.Y., 2006. Toward a unified theory of the CSPCFP link. J. Bus. Ethics, 67: 191-200. DOI: $10.1007 / \mathrm{s} 10551-006-9023-7$

Maskun, A., 2013. Leverage level, company size, profitability toward the disclosure of Corporate Social Responsibility (CSR) of Lq-45 companies in Indonesia stock exchange. Int. J. Acad. Res., 5: 140-144.

McWilliams, A. and D. Siegel, 2000. Corporate social responsibility and financial performance: Correlation or misspecification? Strategic Manage. J., 21: 603-609. DOI: 10.1002/(SICI)10970266(200005)21:5<603::AID-SMJ101>3.0.CO;2-3

McWilliams, A., D.S. Siegel and P.M. Wright, 2006. Corporate social responsibility: Strategic implications. J. Manage. Studies-Oxford, 43: 1-13. DOI: $10.1111 / \mathrm{j} .1467-6486.2006 .00580 . \mathrm{x}$

Moneva, J.M., J.M. Rivera-Lirio and M. Mu Oz-Torres, 2007. The corporate stakeholder commitment and social and financial performance. Industrial Manage. Data Syst., 107: 84-102.

DOI: $10.1108 / 02635570710719070$

Muthuri, J.N., J. Moon and U. Idemudia, 2012. Corporate innovation and sustainable community development in developing countries. Bus. Society, 51: 355-381. DOI: 10.1177/0007650312446441
Namrouqa, H., 2009. Auto-emissions key factor in poor air quality. Report Jordan Times.

Nuryaman, 2013. The effect of corporate social responsibility activities on profitability and stock price (Studies on The companies listed on Indonesia stock exchange). Proceedings of the 4th International Conference on Business and Economic Research Proceeding, (ERP' 13), pp: 113-113.

Orlitzky, M., F.L. Schmidt and S.L. Rynes, 2003. Corporate social and financial performance: A metaanalysis. Organiz. Studies, 24: 403-441.

DOI: $10.1177 / 0170840603024003910$

Park, S.Y. and S. Lee, 2009. Financial rewards for social responsibility: A mixed picture for restaurant companies. Cornell Hotel Restaurant Administrat. Q., 50: 168-179. DOI: 10.1177/1938965509331814

Peccei, R., H. Bewley, H. Gospel, P. Willman and P.E. Street, 2005. Is it good to talk? Information disclosure and organizational performance in the UK. Brit. J. Industrial Relations, 43: 11-39. DOI: $10.1111 / \mathrm{j} .1467-8543.2005 .00343 . \mathrm{x}$

Porwal, L.S. and N. Sharma, 1991. Social responsibility disclosures by Indian companies. Chartered Accountant, 39: 630-635.

Raheman, A. and M. Nasr, 2007. Working capital management and profitability-case of Pakistani Firms. Int. Rev. Bus. Res., 3: 279-300.

Rettab, B., A.B. Brik and K. Mellahi, 2009. A study of management perceptions of the impact of corporate social responsibility on organizational performance in emerging economies: The case of Dubai. J. Bus. Ethics, 89: 371-90. DOI: 10.1007/s10551-008-0005-9

Reverte, C., 2009. Determinants of corporate social responsibility disclosure ratings by Spanish listed firms. J. Bus. Ethics, 88: 351-366. DOI: $10.1007 / \mathrm{s} 10551-008-9968-9$

Rouf, A., 2011. The corporate social responsibility disclosure: A study of listed companies in Bangladesh. Bus. Econom. Res. J., 2: 19-32.

Saleh, M., N. Zulkifli and R. Muhamad, 2008. An empirical examination of the relationship between corporate social responsibility disclosure and financial performance in an emerging market. University of Malaya.

Sharif, M. and K. Rashid, 2014. Corporate governance and Corporate Social Responsibility (CSR) reporting: An empirical evidence from Commercial Banks (CB) of Pakistan. Quality Quantity, 48: 2501-2521. DOI: 10.1007/s11135-013-9903-8

Suwaidan, M.S., 2004. Social responsibility disclosure and corporate characteristics: The case of Jordanian industrial companies. Int. J. Account. Audit. Perform. Evaluat., 1: 432-447. DOI: 10.1504/IJAAPE.2004.006355 
Toms, J.S., 2002. Firm resources, quality signals and the determinants of corporate environmental reputation: Some UK evidence. Brit. Account. Rev., 34: 257-82. DOI: $10.1006 /$ bare.2002.0211

Trapani, A.M.D., R. Squatrito, M. FoderÃ, R. Testa and S. Tudisca et al., 2014. Payment for environmental services for the sustainable development of the territory. Am. J. Environ. Sci., 10: 480-488. DOI: 10.3844 /ajessp.2014.480.488

Turker, D., 2009. How corporate social responsibility influences organizational commitment. J. Bus. Ethics, 89: 189-204. DOI: 10.1007/s10551-008-9993-8

Ullmann, A.A., 1985. Data in search of a theory: A critical examination of the relationships among social performance, social disclosure and economic performance of U.S. Firms. Acad. Manage. Rev., 10: 540-557. DOI: 10.5465/AMR.1985.4278989
UNDP, 2011. Ministry of planning and international cooperation. Jordan Human Development Report, United Nations Development Programme.

WBCSD, 1999. Corporate Social Responsibility: Meeting Changing Expectations. 1st Edn., World Business Council for Sustainable Development, Conches-Geneva, pp: 30.

Wright, P. and S.P. Ferris, 1997. Agency conflict and corporate strategy: The effect of divestment on corporate value. Strategic Manage. J., 18: 77-83. DOI: $10.1002 /($ SICI $) 1097-$ 0266(199701)18:1<77::AID-SMJ810>3.0.CO;2-R

Zur, A.J., J. Evans and K. Bridson, 2008. CSR orientation and organizational performance in the Australian retail industry. Melbourne Business School, Melbourne. 